Arab World English Journal (AWEJ) Special Issue on Covid 19 Challenges April 2021

$222-234$

DOI: https://dx.doi.org/10.24093/awej/covid.17

\title{
ESP Students' Satisfaction with Online Learning during the COVID-19 Pandemic in Ukraine
}

\author{
Nataliia Avsheniuk \\ Foreign Systems of Pedagogical and Adult Education Department, \\ Ivan Ziaziun Institute of Pedagogical and Adult Education of the NAES of Ukraine, Kyiv \\ Nataliya Seminikhyna \\ Department of Foreign languages, Faculty of Economics, \\ Taras Shevchenko National University of Kyiv, Ukraine \\ Corresponding Author: nseminikhyna@gmail.com \\ Tetiana Svyrydiuk \\ Department of Foreign Languages, Faculty of Economics, \\ Taras Shevchenko National University of Kyiv, Ukraine \\ Olena Lutsenko \\ Department of Foreign Languages for Natural Sciences Faculties, Institute of Philology, Taras \\ Shevchenko National University of Kyiv, Ukraine
}

Recieved: 3/1/2021

Accepted: 4/18/2021

Published: 4/26/2021

\section{Abstract}

This study aims to determine the level of ESP students' satisfaction with online ESP learning courses at three faculties of Taras Shevchenko National University of Kyiv. The current study examines students' answers to identify their satisfaction in ESP online courses. The study's research questions were divided into four categories: the effectiveness of online ESP learning, the availability of learning material used by ESP instructors, the evaluation of ESP teachers' results, the effectiveness of online testing, and students' difficulties with ESP distance learning. A descriptive statistical method was used to validate the study. The statistics package JASP was used for data analysis. The authors chose observation, literature analysis, a questionnaire provision, and descriptive data analysis as the research tools. The study results show that students are primarily pleased with ESP courses taught online, students fulfil the expected progress in ESP learning performance. It is revealed that the main problems that influence and impact online ESP learning during COVID-19 are related to technical, academic, and communication challenges. Student satisfaction surveys may lead to changes in ESP online learning activities that may, in turn, boost students' outcomes. The results provide valuable insight into students' satisfaction with online learning and pose practical questions for its implementation. As a result, this study is just a preliminary attempt at offering considerate analysis to Ukraine's policymakers.

Keywords: COVID-19 pandemic, challenges and advantages of ESP online learning, online learning, students' satisfaction, Taras Shevchenko National University of Kyiv

Cite as: Avsheniuk, N., Seminikhyna, N., Svyrydiuk, T., \& Lutsenko, O. (2021). ESP Students' Satisfaction with Online Learning during the COVID-19 Pandemic in Ukraine. Arab World English Journal (AWEJ) Special Issue on Covid 19 Challenges. (1) 222-234.

DOI: https://dx.doi.org/10.24093/awej/covid.17 
Arab World English Journal (AWEJ) Special Issue on Covid 19 Challenges April 2021

\section{Introduction}

To prevent the spread of the COVID-19 pandemic, most higher education institutions worldwide abruptly stopped in-class study at the end of March 2020 (UNESCO, 2020b). As a result of these closures, universities have been forced to use online training tools irrespective students' and teachers' competencies in using technological resources (World Bank, 2020). Although online education is not a new pedagogical methodology and has been used in different fields for many years, there is still a lack of competence in integrating online learning platforms in higher education institutions (UNESCO, 2016). The worldwide academic calendar was plunged into a state of disarray by the coronavirus pandemic. Many teachers and students have gone home and self-quarantined at the same time (UNESCO, 2020a). As a solution to this problem, several academic leaders are now supporting online education. (UNESCO, 2020). It is necessary to acknowledge the fact that online education is not a satisfactory substitute for faceto-face delivery. In Ukraine students of the higher education institutions were asked to stay home and continue their studies online. All lectures and seminars were transferred entirely to online learning at Taras Shevchenko National University.

With the ongoing technology development in distance learning and with the introduction of digital teaching technologies, it is crucial to analyse the level of students' satisfaction in online learning. These issues are of great concern to teachers and administrators of the vast majority of universities worldwide, as students are recognized as the most critical stakeholders in higher education. All efforts are made to meet their educational needs and to ensure the quality of teaching and learning. Evidence of this is the statistical research conducted in the UK and the USA. They, in particular, show that the percentage of students' dissatisfaction with the educational process is growing rapidly. It is indicated in a survey by the British Office for National Statistics. In a January survey by the UK's National Statistics Office (ONS), 37\% of students said they were "dissatisfied" or "very dissatisfied" with higher education. It is $8 \%$ more than in November last year. The biggest problems, according to British students, are the teaching methods, teaching materials, and the quality of knowledge. In the UK, it can be explained by the transition of most subjects to the online environment through the third lockdown, which was introduced in early January (Office for National Statistics, 2021).

In Ukraine, as in most countries across the world, studies on students' perception of online learning are also being conducted. The State Quality Service of Education of Ukraine conducted an online survey among teachers and students to analyze their satisfaction with online education and assess the quality of online learning in the 2020/2021 academic year. The survey found various critical challenges in online learning that are considered to influence the quality and efficient study. Such challenges include lack of transparency in the students' assessment, lack of or poor internet connection, insufficient control over students' acquisition of knowledge, a lot of individual learning, and lack of professional competence for teaching online (The State Quality Service of Education of Ukraine, 2020).

The network of Higher Education Reform Experts reports on the Ukrainian situation with online learning at higher education institutions. According to the findings, Ukrainian universities help their students meet their educational targets in these unprecedented times. The flexibility with which online learning is adopted across Ukraine, however, differs significantly. The higher education institutions experienced with Erasmus+ projects have successfully used the projects' 
findings on the creative teaching, learning approaches and instruments of online learning. However, most Ukrainian universities are facing similar problems: 1) there is a shortage of institutional policies and tools to coordinate online learning, 2) the introduction of high-quality multimedia facilities and content is still recent and there is a need to manage the multitude of such services, and 3) teaching personnel have limited knowledge and competence and/or a lack of digital skills (HERE, 2020). The task now is to incorporate new online tools into ordinary teaching activities and to determine the subject areas in which they are already best used and where further progress is needed. As can be seen from the statistics obtained in different countries, further challenges are linked to the teachers' adaptability to tailor lectures for online learning, to track synchronous or asynchronous interaction between students, and to build authentic online appraisal resources that complement the shift from face-to-face courses to online platforms (Watts, 2016).

To boost student performance, more efforts are required by all online educators to combine pedagogy with technology. Among the various types of student engagement, learner-toinstructor engagement techniques seemed to be the most valued. Icebreaker/introduction discussions and working collaboratively in groups by using online communication tools were rated the most effective engagement strategies in the learner-to-learner category. Sending regular announcements or reminders and providing an assessment scale for all assignments were rated most valuable in the learner-to-instructor category. Also, online dialogue as an efficient networking activity was found to be very motivational for students in the new online learning environment. Thus student engagement increases student satisfaction, enhances student motivation to learn, and improves student performance in the online learning environment. As a result, teachers need a deeper understanding of how students perceive and react to elements of online learning (because student expectations and attitudes are vital to motivation and learning) along with how these methods can be more successfully implemented to improve learning (Koohang \& Durante, 2003). Students' roles and responsibilities in collaborative groups are clearly established and emphasized, and teachers' roles are changed from information providers to facilitators of knowledge in online learning. It is better to involve and inspire students by setting challenges to the students and implement it. Such students' involvement increases students' satisfaction (Amena, 2020). This study calls for further studies on integrating professional development seminars and educational workshops for ESP online learning and teaching in order to encourage innovative ESP teaching methods for online learning and alternative evaluation plans for teachers and students. The research aims to determine the level of satisfaction of the students of three faculties at KNU Ukraine with ESP online learning channels and learning environments during lockdown. Student satisfaction surveys may lead to changes in ESP online learning activities that may, in turn, boost students' outcomes. The results provide valuable insight into students' satisfaction with online learning and pose practical questions for its implementation. The study's research questions fell into four categories: the efficiency of online ESP learning experience, the availability of learning material used by ESP instructors, the assessment of ESP teachers' performance, the effectiveness of online testing, and students' difficulties with ESP distance learning.

\section{Literature Review}

The analysis of the literature shows that most studies are conducted to classify students' perceptions and attitudes toward online learning, and studies relating to students' perceptions of 


\section{Arab World English Journal (AWEJ) Special Issue on Covid 19 Challenges April 2021}

online learning during the COVID-19 pandemic are rare and far between. There are different terms presented for online education in the literature. Some of them are virtual education, Internet-based education, web-based education, and education via computer-mediated communication. The authors choose the definition of online education that is based on Keegan's (1988) definition of distance education. Keegan (1996) analyzed reports of distance education and incorporated the following form of education into five characteristics: separation of teacher and learner throughout the length of the learning process; the impact of an academic institution in the preparation and planning of learning materials as well as the availability of student support services; the use of electronic media (print, audio, video, or computer) to link teacher and learner and deliver course material; the availability of two-way communication so that the student may benefit from or even initiate this form of communication (Keegan, 1996).

Sinclaire highlighted that online learning is a massive difference in how students learn and, in addition, how students are taught. Therefore, the point is that there is a growing need to consider what leads to student satisfaction with online learning (Sinclaire, 2011).

In creating a successful online program, Sener and Humbert (2003) claimed that satisfaction is a vital component. Satisfaction can be characterized as "a definition that reflects results and reciprocity between students and an instructor"(Thurmond, Wambach, Connors \& Frey, 2002, p.171). Learner satisfaction of a course is one of the significant pillars for evaluating the success and efficacy of the course delivery. In evaluating student satisfaction with online courses Richardson and Swan (2003) concentrated on the relationship of teacher social presence in online learning that influenced students' satisfaction. They discovered a strong connection between the perceptions of students' social involvement and their perceptions of online learning. Bollinger (2004) found three constructs to be important: interactivity, teacher variables and technology problems. Yet, developing an online environment that promotes student satisfaction requires methods that go beyond facilitating interaction with components of the course. Interaction with each other, between a student and a teacher and between students in the course, often includes creating culture, among other elements. Sher (2009) discovered that interactions between student and teacher and between students are essential factors in student satisfaction. Multiple studies have shown that a student's active participation in the learning process improves learning, a process known as active learning (Sarason \& Banbury, 2004). Good learning results were obtained by interactive teaching or "learning by doing" (Picciano, 2002).

When it comes to learner motivation, satisfaction, and engagement, the online learning environment differs dramatically from the conventional classroom environment (Bignoux \& Sund, 2018). Because many new technologies and web-based activities are interactive, online learning can build environments where students engage with the material and learn by doing, improving their understanding as they build new skills (Johnston, Killion \& Omomen, 2005).

Some pedagogical methods can be more easily converted into online learning and distance learning environments than others. Teaching activities that rely heavily on instructor lectures or the teacher assigning self-study materials are more readily transferable to online learning environments than more advanced pedagogical approaches. Those approaches are usually discovered where students complete the tasks that are more learner-centered or projectbased (Anderson \& Dron, 2010). The surveys include a range of explanations why, with online 
studies, students can learn successfully. Students have more influence over their research, according to the findings, and have more choices available for reflection at their hands.

In the field of language education, teachers have taken an interest in modeling studentoriented courses using the latest web tools for courses that have been mainly instructor- oriented. Based on the main functions and features of the language learning, online tools are grouped into twelve categories (Son, 2011). For this study the authors chose the tools that are frequently used during ESP classes at the university, such as content management, communication, live and virtual worlds, social networking and bookmarking, resource sharing, Web exercise creation, and Web search engines. ESP courses have similar challenges. The authors decided to research what affects students' satisfaction in learning ESP online and what learning tools lead to student performance improvement in the lockdown.

\section{Methods}

The study's data are based on students' experiences completing an online ESP course during lockdown. This research aims to determine the level of satisfaction of the students of three faculties at KNU Ukraine with ESP online learning channels and learning environments during lockdown. Data collected were analyzed using the Statistical Package JASP. Appropriate statistical procedures for description (frequencies, percentages, means, and standard deviations) were used. Students answered the questions in a Google questionnaire. Based on a literature review, a questionnaire was developed to collect the necessary data. The questionnaire covered four areas and consisted of a list of questions in each section. As research tools the authors also chose observation, literature analysis, a questionnaire provision, and descriptive data analysis.

\section{Research questions}

The current study examines students' answers to identify students' satisfaction in ESP online courses. The Google questionnaire was divided into four dimensions: the efficiency of online ESP learning experience, availability of learning material used by ESP teachers, assessment of ESP teachers' performance, efficiency of online testing, and students' challenges with ESP distance learning. Questionnaires were sent out and consisted of 23 survey questions sorted into four dimensions: How would you evaluate your ESP online course experience? How would you assess the efficiency of ESP learning materials used in ESP classes? How would you assess your ESP teacher's performance in a virtual class? How would you consider ESP online testing?

\section{Participants}

The site for this study was the Faculty of Economics, the Faculty of Biology, and the Faculty of Geography where an ESP course is taught for students of the first and second years of study at KNU, Ukraine.

This study used a selective student satisfaction evaluation model. The study population was ESP students of three faculties of KNU of the first and second years of study who take ESP courses and participate in online learning. The sampled group is made up of 167 students who were targeted for the survey. The participants' ages range from 17-19. The survey was conducted in English, and no translation was necessary to be added. 
Arab World English Journal (AWEJ) Special Issue on Covid 19 Challenges April 2021

\section{Research Procedures}

Respondents who participated in the ESP online learning programs of three different faculties were invited to complete the questionnaire. Responses to each question in the survey were imported into a JASP statistical package from Google forms, and respondents' complete data for each question was put in the JASP interface. Anonymous completed questionnaires, and the received results were analyzed. A descriptive-correlation survey approach was used in this study.

\section{Data Collection}

The ESP students' answers were collected and saved in the Google documents. Data were collected over two months from October to December 2020. The survey took the participants about eight minutes to complete. The 167 forms and the accompanying comments samples formed the data set for subsequent analysis.

\section{Findings}

The questionnaire was divided into four sections where the first section highlighted the ESP students' satisfaction with their ESP learning experience online. In the second section of the questionnaire, the students' satisfaction with the ESP learning materials offered and used by their ESP teacher was assessed. In the third section the level of students' satisfaction with their teacher's competence and performance online was evaluated. The fourth section of the survey represented the student's satisfaction with the transparency of online assessment.

\section{How would you assess your ESP online course experience?}

Regarding answering the questions in the first section: How would you assess your ESP online course experience? Students reported that they were satisfied with the selected method, facilitating their learning outcomes of the course's objectives. Quantitative data were obtained by asking students to indicate if they are satisfied or dissatisfied with a series of statements about their experiences and preferences regarding the use of the online learning tools on a five point Likert scale ( $1=$ Fair and 5=Excellent). The results from the survey suggest that the students view online learning experience as satisfying. Table one provides a summary of the results obtained. As indicated in Table one, the respondents rated two items as being of "high importance" and sixth items as being of "average importance. " The two highest-rated items were "Willingness to continue studying ESP online" and "Ability to meet the deadlines. " Analysis shows that the students are mostly satisfied with the offered ESP online learning experience during the COVID19 pandemic. Furthermore, it was determined that course delivery methods and tools $(4,396)$, were effective during a rapid shift to online teaching during COVID-19. As a first-time experience, the results showed a highly satisfactory achievement of learning outcomes. Participants were satisfied with course engagement activities levels $(4,317)$, ability to meet the deadlines where the mean is $(4,617)$ and the results obtained represent an increased ability to manage time while studying online. Students reported a high level of motivation to learn ESP online $(4,377)$, their willingness to continue study ESP online showed more than good results $(4,377)$, increased opportunity to access and use information showed $(4,120)$ that have a positive attitude to online ESP experience where shift to online ESP learning increased attendance of ESP courses $(4,333)$. 
Arab World English Journal (AWEJ) Special Issue on Covid 19 Challenges April 2021

ESP Students' Satisfaction with Online Learning

Avsheniuk, Seminikhyna, Svyrydiuk, \& Lutsenko

Table 1. Students' perceptions of their ESP online course experience

\begin{tabular}{|l|l|l|l|l|l|l|l|l|}
\hline & $\begin{array}{l}\text { Course } \\
\text { engagemen } \\
\text { t activities }\end{array}$ & $\begin{array}{l}\text { Ability } \\
\text { to meet } \\
\text { the } \\
\text { deadline } \\
\text { s }\end{array}$ & $\begin{array}{l}\text { Student's } \\
\text { motivatio } \\
\text { n to learn } \\
\text { ESP } \\
\text { online }\end{array}$ & $\begin{array}{l}\text { Willingnes } \\
\text { s to } \\
\text { continue } \\
\text { studying } \\
\text { ESP online }\end{array}$ & $\begin{array}{l}\text { Opportunit } \\
\text { y to access } \\
\text { and use } \\
\text { information } \\
\text { r }\end{array}$ & $\begin{array}{l}\text { Satisfactio } \\
\text { n with ESP } \\
\text { content } \\
\text { online }\end{array}$ & $\begin{array}{l}\text { Deliver } \\
\text { y } \\
\text { method } \\
\text { s and } \\
\text { tools } \\
\text { used }\end{array}$ & $\begin{array}{l}\text { Attendanc } \\
\text { e of ESP } \\
\text { course } \\
\text { online }\end{array}$ \\
\hline Valid & 167 & 167 & 167 & 167 & 167 & 167 & 144 & 144 \\
\hline Missing & 0 & 0 & 0 & 0 & 0 & 0 & 23 & 23 \\
\hline Mean & 4.317 & 4.617 & 4.377 & 4.743 & 4.120 & 4.377 & 4.396 & 4.333 \\
\hline $\begin{array}{l}\text { Std. } \\
\text { Deviatio } \\
\mathrm{n}\end{array}$ & 0.737 & 0.500 & 0.691 & 0.439 & 0.775 & 0.522 & 0.692 & 0.626 \\
\hline Min & 3.000 & 4.000 & 3.000 & 2.000 & 3.000 & 3.000 & 3.000 & 3.000 \\
\hline Max & 5.000 & 5.000 & 5.000 & 5.000 & 5.000 & 5.000 & 5.000 & 5.000 \\
\hline
\end{tabular}

How would you assess ESP learning materials used in ESP classes?

The answers given in the second section about students' satisfaction with chosen learning materials used in their online ESP course show that the most effective and convenient media for ESP classes were ZOOM, Google Classroom, and Google Hangouts. The students' perceptions of the most effective online learning methods and platforms are varied. Quantitative data was obtained by asking students to indicate if they have a positive perception of learning materials -1 or have a negative attitude - 0 to their experiences and preferences regarding the use of online learning tools. Overall, the results from the survey suggest that the students view online learning materials as effective. Concerning the ability to work with the ESP teachers' guides on their own, students reported that they could do it themselves $(0,720)$. Students understand ESP course requirements better in an ESP online course than in an in-class (0.738). They show high satisfaction with online resources chosen by the ESP teachers $(0,707)$. Overall, the students are delighted with the online classes and the tools used for class deliveries.

Table 2. Efficiency of ESP learning materials used in ESP classes

\begin{tabular}{|l|l|l|l|l|}
\hline & $\begin{array}{l}\text { I can work with the } \\
\text { ESP teachers } \\
\text { guides on my own }\end{array}$ & $\begin{array}{l}\text { I can understand } \\
\text { ESP course } \\
\text { requirements better } \\
\text { in an online course } \\
\text { than in an in-class } \\
\text { course }\end{array}$ & $\begin{array}{l}\text { I am satisfied with } \\
\text { online resources } \\
\text { chosen by the ESP }\end{array}$ & $\begin{array}{l}\text { I find video-based } \\
\text { ESP classes an } \\
\text { effective way of } \\
\text { learning }\end{array}$ \\
\hline Valid & 167 & 167 & 167 & 148 \\
\hline Missing & 0 & 0 & 0 & 19 \\
\hline Mean & 0.720 & 0.738 & 0.707 & 0.716 \\
\hline Std. Deviation & 0.451 & 0.441 & 0.456 & 0.452 \\
\hline Minimum & 0.000 & 0.000 & 0.000 & 0.000 \\
\hline Maximum & 1.000 & 1.000 & 1.000 & 1.000 \\
\hline
\end{tabular}


How would you assess your ESP teacher's performance in virtual class?

Regarding the questions in section three rating teacher's competence and performance, students assessed teachers in the online class overall (Good). They were almost satisfied with teachers' performance in a virtual class. The survey results suggest that the teachers' performance in a virtual class is favorable for achieving learning outcomes. Table three provides a summary of the results obtained. As indicated in Table three, the respondents rated one item as being of "high importance" and five items as being of "average importance". The highest rated item was "teacher's presence in the virtual classes", which represents a vital role of a teacher and facilitator in online learning. The second - highest ranked thing was opportunities to collaborate with other students during online ESP classes, group work and interactivity of classes $(4,598)$ which indicates the necessity of group work during ESP classes. Moreover, it was identified that teacher's communication was adequately effective and participants are satisfied with the means of communication chosen by their ESP teacher $(4,317)$. Surprisingly the time response from the ESP teachers and feedback from them was not as quick as students expected, and answers to this research question gave less than $(4,287)$ satisfied students. Consequently, it influenced the final result of students' satisfaction with their teachers' performance.

Table 3. Assessment of ESP teacher's performance in a virtual class

\begin{tabular}{|c|c|c|c|c|c|}
\hline & $\begin{array}{l}\text { Means of } \\
\text { communication } \\
\text { chosen by their } \\
\text { ESP teacher }\end{array}$ & $\begin{array}{l}\text { Collaboration } \\
\text { with other } \\
\text { students }\end{array}$ & $\begin{array}{l}\text { Time response } \\
\text { from the ESP } \\
\text { teacher }\end{array}$ & $\begin{array}{l}\text { Teacher's } \\
\text { presence in } \\
\text { the virtual } \\
\text { classes }\end{array}$ & $\begin{array}{l}\text { Cooperation } \\
\text { with the ESP } \\
\text { teacher }\end{array}$ \\
\hline Valid & 167 & 167 & 167 & 167 & 167 \\
\hline Missing & 0 & 0 & 0 & 0 & 0 \\
\hline Mean & 4.317 & 4.598 & 4.287 & 4.701 & 4.372 \\
\hline Std. Deviation & 0741 & 0.504 & 0.820 & 0.459 & 0.702 \\
\hline Minimum & 2.000 & 3.000 & 1.000 & 4.000 & 3.000 \\
\hline Maximum & 5.000 & 5.000 & 5.000 & 5.000 & 5.000 \\
\hline
\end{tabular}

How would you assess ESP online testing?

In answering the fourth section on transparency and accuracy of ESP online testing, students reported that they were satisfied with the selected online exam platforms, namely Exam.net and Socrative which were highly rated by respondents. As indicated in Table four, the respondents rated two items as "highly-rated" and four items as being "lower-rated". The results from the survey suggest that online performance testing was assessed transparently and accurately. Despite of the high level of difficulty of the exam tasks (4.741) it did not influence the final result for the course. Monitoring academic performance in online ESP classes in its turn was rated as higher than moderate (4.377), instructions were clear and easy to follow. 
Arab World English Journal (AWEJ) Special Issue on Covid 19 Challenges April 2021

Table 4. Assessment of ESP online testing

\begin{tabular}{|l|l|l|l|l|l|}
\hline & $\begin{array}{l}\text { How would you } \\
\text { evaluatethe level } \\
\text { of difficulty of the } \\
\text { Midterm exam? }\end{array}$ & $\begin{array}{l}\text { How would } \\
\text { you assess } \\
\text { the level of } \\
\text { difficulty of } \\
\text { the tasks } \\
\text { during a } \\
\text { semester? }\end{array}$ & $\begin{array}{l}\text { Were the exam } \\
\text { instructions } \\
\text { clear and } \\
\text { transparent in } \\
\text { the } \\
\text { assessment? }\end{array}$ & $\begin{array}{l}\text { Was } \\
\text { assessment } \\
\text { of your } \\
\text { academic } \\
\text { progress } \\
\text { accurate in } \\
\text { online ESP } \\
\text { classes? }\end{array}$ & $\begin{array}{l}\text { Was it easy to } \\
\text { monitor your } \\
\text { academic } \\
\text { performance in } \\
\text { online ESP } \\
\text { classes? }\end{array}$ \\
\hline Valid & 167 & 167 & 167 & 160 & 167 \\
\hline Missing & 1 & 1 & 1 & 7 & 0 \\
\hline Mean & 4.373 & 4.741 & 4.337 & 4.506 & 4.377 \\
\hline Std. Deviation & 0.700 & 0.439 & 0.638 & 0.644 & 0.556 \\
\hline Minimum & 3.000 & 3.000 & 3.000 & 3.000 & 2.000 \\
\hline Maximum & 5.000 & 5.000 & 5.000 & 5.000 & 5.000 \\
\hline
\end{tabular}

Correlation between selected dependent variables with student's perception of ESP online learning

The Pearson coefficient of correlation was used to identify the correlation between selected dependent variables with perception regarding ESP online course during the pandemic. The relationship between some selected respondents' characteristics with perception of students' satisfaction of ESP online is presented in Table five. There was a significant relation found between the level of course engagement activities and students' motivation and opportunity to assess and use information with delivery methods and tools used by their ESP teacher.

Table 5. Correlation between selected dependent variables with student's perception of ESP online learning

\begin{tabular}{|l|l|l|l|}
\hline $\begin{array}{l}\text { Course engagement } \\
\text { activities }\end{array}$ & $\begin{array}{l}\text { Students' motivation to learn } \\
\text { ESP online }\end{array}$ & $0.745 * * *$ & $\mathrm{p}$ \\
\hline $\begin{array}{l}\text { Opportunity to access } \\
\text { and use information }\end{array}$ & $\begin{array}{l}\text { Delivery methods and tools } \\
\text { used in ESP online }\end{array}$ & $0.599 * * *$ & $<.001$ \\
\hline
\end{tabular}

\section{Discussion}

The aim of this research was to investigate students' attitudes toward online ESP courses in terms of social presence, social interaction, engagement and satisfaction. Furthermore, the aim of this study was to investigate the perception of ESP online learning versus among students. The survey results show that a level of course engagement activities leads to students' motivation, and having an opportunity to assess and use information with delivery methods and tools used by their ESP teacher increases the student's satisfaction with ESP online learning. Interactive instruction or "learning by doing" resulted in positive learning outcomes (Picciano, 2002; Watkins, 2005). Richardson and Swan (2003) concentrated on the relationship of teacher social presence in online learning and students' satisfaction. They discovered a strong connection between the perceptions of students' social involvement and their perceptions of online learning. 
Our study showed that the four highest rated advantages of online learning were "teachers presence in the virtual classes", "flexibility in time and place", "quick sharing of learning materials for students and collaboration with other students".

Moreover, online learning encourages students to work at their own speed to complete their tasks. As a result, in order to experience class participation, instructors must have a solid understanding of both theory and practice of online learning.

\section{Conclusion}

The unprecedented situation with COVID-19 had a significant impact on university education in Ukraine. It is crucial to tailor and adjust teaching methods and tools and create a favorable environment for teaching and online learning in universities. The quarantine gave a push to rapid and effective transformations in the higher education system of Ukraine. Online learning plays a vital role in higher education, it is important for universities to focus on students' perception and their expectations towards the role of online learning within their higher education experiences.

This study concludes that the students are satisfied with the ESP teachers who created a comfortable ESP online environment in times of COVID-19, where they agreed on specific teaching rules to use, assessment choices, training workshops, and online technical support. Students are also satisfied with the facilities provided by the ESP teachers.

Regarding their most effective online learning platforms, it is concluded that ZOOM is the most effective tool for lecture delivery after Google Classroom.

Overall, all the students are delighted with online teaching during COVID-19. The study revealed that the students are content with the assessment types. The assessment plans used by teachers are perceived as favourable for gaining course knowledge and skills. An efficiently tailored ESP online course uses various teaching tools and services to increase students' performance. ESP online in the university offers more accessibility and freedom.

The effectiveness and success of ESP online courses at the university rely mainly on the nature of the course content, the outline of the course content, the contact between the student, and the teacher, and the availability of learning materials. The study found that teachers' presence and support play an essential role in acquiring knowledge online. In both individual and group work, teachers initiate interaction. ESP teachers respond to the learners' questions, design projects, and evaluate their learning because student expectations and attitudes are vital to motivation and learning. It is important to remember that technology may not be capable of replacing a teacher. Our study showed that teachers' communication was effective enough and participants are satisfied with the means of communication chosen by their ESP teachers. If that is the case, research needs to be done on a wide scale to promote the refinement of ESP teaching and learning processes.

The study presented here focused on students' satisfaction with ESP online learning among students with mostly limited prior online learning experience. The findings provide important insight into students' satisfaction with online learning and raise practical 
considerations for its implementation. This study is thus just an initial attempt at providing insightful analysis to the policymakers of Ukraine.

Additional studies are recommended to extend research on both professors' and students' satisfaction with their overall perception, such as willingness to use online learning, their need for educational technology, as well as technical assistance and training support. A gap actually remains that needs to be filled. Future studies should perhaps be specifically concerned with carrying out an in-depth analysis of the activities to be implemented, such as online training practices, ESP online teaching, development process, and a more detailed course design guidance. In order to promote new ESP teaching strategies for online learning and alternative evaluation plans for teachers and students, this study calls for more research about incorporating career development seminars and educational workshops for ESP online learning and teaching.

Collecting data on the benefits and challenges of online teaching and learning during the unprecedented COVID-19 pandemic would also be appropriate for teachers and administrators who are to design strategies for future crises.

About the Authors:

Nataliia Avsheniuk, Doctor of Science in Education. The Ivan Ziaziun Institute of Pedagogical and Adult Education of the NAES of Ukraine, Head of the Foreign Systems of Pedagogical and Adult Education Department; Member of the National Agency for Higher Education Quality Assurance; Deputy editor-in-chief of the scientific journal Comparative Professional Pedagogy. ORCID ID: 0000-0003-1012-005X

Nataliya Seminikhyna, PhD student (Pedagogy)at the Ivan Ziaziun Institute of Pedagogical and Adult Education of the NAES of Ukraine, Assistant professor. Department of Foreign Languages, Faculty of Economics, Taras Shevchenko National University of Kyiv. ORCID ID: 0000-0001-6246-4132

Tetiana Svyrydiuk, PhD (Linguistics), Assistant Professor. Department of Foreign Languages, Faculty of Economics, Taras Shevchenko National University of Kyiv. ORCID ID: 0000-00019482-8228

Olena Lutsenko, PhD (Education), Assistant Professor. Taras Shevchenko National University of Kyiv, Institute of Philology, Department of Foreign Languages for Natural Sciences Faculties ORCID ID: 0000-0002-6864-908X

\section{References}

Amena, M. (2020). The Role of Problem Based Learning in Engaging and Empowering Omani EAP Learners: An Exploratory Study. Arab World English Journal (AWEJ). Proceedings of 2nd MEC TESOL Conference 2020, 184-196. DOI: https://dx.doi.org/10.24093/awej/MEC2.13

Anderson, T., \& Dron, J. (2010). Three generations of distance education pedagogy. The International Review of Research in Open and Distance Learning, 12(3), 80-97. DOI: https://doi.org/10.19173/irrodl.v12i3.890

Bignoux S., \& Sund, K. (2018). Tutoring executives online: What drives perceived quality? 
Arab World English Journal (AWEJ) Special Issue on Covid 19 Challenges April 2021

Behaviour \& Information Technology, 37 (7), 703-713.

Bollinger, D. U., \& Martindale, T. (2004). Key factors for determining student satisfaction in online courses. International Journal on E-Learning, 3(1), 61-67.

HERE. (2020). Ukrainian Higher Education responds to the COVID-19 challenges. Retrieved from: https://supporthere.org/news/ukrainian-higher-education-responds

Johnston, J., Killion J., \& Oomen, J. (2005). Student Satisfaction in the Virtual Classroom. The Internet Journal of Allied Health Sciences and Practice, 3(2). Available at https://nsuworks.nova.edu/ijahsp/vol3/iss2/6/.

Keegan, D. (1988). The foundations of distance education. London: Croom Helm.

Keegan, D. (Ed.) (1996). Foundations of distance education ( $3^{\text {rd }}$ ed.). London: Routledge.

Koohang, A., \& Durante, A. (2003). Learners' perceptions toward the web-based distance learning activities/assignments portion of an undergraduate hybrid instructional model. Journal of Informational Technology Education 2, 105-113.

OECD. (2020). Supporting-the-continuation-of-teaching-and-learning-during-the-COVID-19pandemic: Annotated References for On-line Learning. Available at https://www.oecd.org/education/Supporting-the-continuation-of-teaching-and-learningduring-the-COVID-19-pandemic.pdf.

Office for National Statistics. (2021). Student Covid Insights Survey Experimental Statistics, England. Retrieved from: ons.gov.uk.

Picciano, A. (2002). Beyond student perceptions: Issues interaction, presence, and performance in an online course. Journal of Asynchronous Learning Networks, 6(1), 20-41. DOI: 10.24059/olj.v6i1.1870.

Richardson, \& Swan, K. (2003). An Examination of Social Presence in Online Courses in Relation to Students' Perceived Learning and Satisfaction. Journal of Asynchronous Learning Networks, 7(1),68-88. DOI: 10.24059/olj. v7i1.1864.

Sarason ,Y., \& Banbury, C. (2003). Active Learning Facilitated by Using a Game-Show Format or Who Doesn't Want to be a Millionaire? Computer Science. Journal of Management Education, 4, 509-518.

Sener, J., \& Humbert, J. (2003). Student satisfaction with online learning: An expanding universe. Elements of Quality Online Education: Practice and Direction, 4, 245-260.

Sher, A. (2009). Assessing the relationship of student-instructor and student-student interaction to student learning and satisfaction in web-based online learning environment. Journal of Interactive Online Learning, 8, 102-120.

Sinclaire, J. K. (2011). Student satisfaction with online learning: Lessons from organizational behavior. Research in Higher Education Journal, 11, 1-20.

Son. J. (2011). Online tools for Language Teaching. Teaching English as a Second or Foreign Language, 15(1). Available at http://www.teslej.org/wordpress/issues/volume15/ej57/ej57int/.

Swan, K. (2003). Learning effectiveness: What the research tells us. In J. Bourne, \& J. C Moore, (eds.), Elements of Quality Online Education, Practice and Direction (pp. 13-45). Needham MA: Sloan Center for Online Education.

The State Quality Service of Education of Ukraine. SQE. (2020) Information and analytical reference about the results of the survey on the use of technologies during distance learning in higher education institutions of Ukraine. Retrieved from: http://www.sqe.gov.ua/.

Thurmond, W., \& Conners, Frey, (2002). Evaluation of Student Satisfaction: Determining the 
Impact of a Web-Based Environment by Controlling for Student Characteristics. American Journal of Distance Education, 16(3), 169-89.

UNESCO. (2016). Open Educational Resources: Policy, Costs and Transformation. Available at https://unesdoc.unesco.org/ark:/48223/pf0000244365.

UNESCO. (2020a). COVID-19 Educational Disruption and Response. Available at https://en.unesco.org/covid19/educationresponse/.

UNESCO. (2020b). Crisis-sensitive educational planning. Paris: UNESCO. Retrieved from http://www.iesalc.unesco.org/en/wp-content/uploads/2020/04/COVID-19-EducationIssue-Note-2.4-Planning.pdf.

Watts, L. (2016). Synchronous and asynchronous communication in distance learning. Quarterly Review of Distance Education, 17(1), 23-32.

World Bank (2020). Guidance Note: Remote Learning and COVID-19. Retrieved from http://documents.worldbank.org/curated/en/531681585957264427/pdf/Guidance-Noteon-Remote-Learning -and-COVID-19.pdf.

\section{Appendices \\ Appendix A \\ Students' questionnaire}

\section{Dimension 1. Online ESP learning experience \\ 1. How would you evaluate your ESP online} course experience?

2.What tools did you find most useful?

3.Would you like to go on studying ESP this way?

4. Did you have enough opportunities to reflect on what you have learned in online ESP classes?

5. Has your online experience increased your opportunity to access and use information?

6. Are you motivated in ESP classes?

7. Do you meet deadlines?

8. Did online learning increase the attendance of ESP classes?

Dimension 2. ESP learning materials used

1. What platforms were used for your online ESP course?

2. Were you able to work with the ESP teachers guides on your own?

3. Did you find video-based ESP classes effective?

4. Do you think that the online resources chosen by the ESP teachers were useful to study the ESP course?

5. Did you ESP course online increase your understanding of requirements in an online course?
Dimension 3. ESP teacher's performance

1. How would you assess teachers' performance in the virtual classes?

2. Do you think that your and ESP teachers' cooperation was effective?

3. Did you have any opportunities to collaborate with other students during online ESP classes?

4. Was response time from ESP teachers quick in online classes?

Dimension 4. ESP online testing

1. What online platforms did the ESP teacher used for testing?

2. How would you assess the level of difficulty of the Midterm exam?

3. How would you assess the level of difficulty of the tasks?

4.Were the exam instructions clear and transparent in the assessment?

5.Was assessment of your academic progress accurate in online ESP classes?

6.Was it easy to monitor your academic performance in online ESP classes? 